\title{
Physiological Quality in Seeds Obtained by Topcrosses Between Vegetable Soybean and Grain Type
}

\author{
Gilberto K. Yokomizo ${ }^{1^{*}}$ and Natal A. Vello ${ }^{2}$ \\ ${ }^{1}$ EMBRAPA/CPAFAP, Rod. Juscelino Kubitschek, km 05, Caixa Postal 10, CEP 68902-280, Macapá-AP, Brazil. \\ ${ }^{2}$ Departamento de Genética-ESALQ/USP, Caixa Postal 83, CEP 13400-970, Piracicaba-SP, Brazil
}

\begin{abstract}
Attempts were made to study the gene introgression for high physiological quality from adapted cultivars in the vegetable soybean (exotic). Promising results were obtained for all topocrosses, with increased in germination percentage in majority. General mean of the germination percentage in topcrosses with large seeds exotic parental showed an increase from 28 to 46\%, and topcrosses with small seeds exotic parental, from 54 up to 60\%, both cases compared to self pollinated exotic parental. Related to variance, the topcrosses showed higher values than the self pollinated exotic parental, showing to be possible the selecion of promising materials.
\end{abstract}

Key words: soybean, Glycine max, topcross, physiological quality in seeds, vegetable soybean.

\section{INTRODUCTION}

Soybean production is about 30 million tons per year in Brazil (Agrianual, 1998), occupying the second position after corn, in terms of grains production, being behind just of the corn. Most of soybean is exported in the form of deflated bran. Recently an increase in the interest of the soybean employment in the human feeding occurred to supply the deficiencies of protein in destitute population from Brazil (Carrão-Panizzi, 1987).

In the oriental countries, soybean consumption for human food directly exist at three thousand years, even so in spite of the high quality nutritional, this doesn't have great acceptance in the Brazilian menus, mainly due the unfamiliarity of the existence of a specific category destined to the human consumption, denominated as soybean type food. The soybean type food includes two subgroups: the first of the vegetable soybean with big seeds (weight of hundred seeds (HSW) larger or equal to 20g), one and the second type broto/nattô with HSW smaller or equal to $10 \mathrm{~g}$, mentioned by Vello, 1992.
A problem presented by soybean type food is the fast germination loss and vigor (Santos, 1988), the physiological quality becomes a preoccupying factor in the improvement of this group (vegetable soybean), whose size of the seeds also predisposes the seeds to the mechanical and physiological damages during the crop and the storage (Vernetti, 1983). Wien \& Kueneman (1981) observed that progenies with seeds of smaller size, in comparison with the one of larger size, were better in the storage, preserving the qualities of germination and vigor, and differences also exist among them in the deterioration rate after the crop, affecting the physiological quality (Green \& Pinnell, 1968; Paschal \& Ellis, 1978). Sung (1992) observed that in the field occurred a larger percentage of emergency in a faster way for the smaller seeds. An interesting data was observed by Rao \& Sharma (1985) studying the germination and its correlations with other characters, the germination in the field presented a positive correlation of 0,017 with seed size, this value is low, even so it should be explored with appropriate methods of selection.

* Author for correspondence 
A possible solution to deal with conservation problem could be the gene introgression for high physiological quality of the seeds from two adapted cultivar (Doko and FT-2), Doko with late cycle and FT-2 with high precocity, efficient strategy according to Kiihl \& Garcia (1989) and Kaster et al. (1989), both cultivars present enough physiological quality to serve of reference in the genetic improvement, searched for this character. In the work of Guerra et al. (1999) the results indicated that some soybean food type can be competitive in terms of production in relation to the adapted grain type, this fact is important, therefore in this way, in many soybean food type will have only the necessity to correct physiological quality problem in the seeds, not the productivity.

\section{MATERIAL AND METHODS}

Genetic material employed in this experiment included 118 genotypes, everybody with seeds of same age and maintained in the storage in similar conditions, being: 72 topcrosses obtained by crossing of 41 exotic materials of big seeds and 3 of small seeds crossings with the two cultivars adapted Doko and FT-2, in that research it was used the generation $\mathrm{F}_{4}$ and its 46 parental.

The genotypes were subdivided in two experiments in random blocks design, the first with 6 repetitions of the 72 progenies $\mathrm{E}_{4}$, the second formed by 2 repetitions of the 46 parentals, sowing on March 13,1991 , the experimental plot was composed by 3 lines with

4 hills each, totality 12 spaced hills of $0,6 \mathrm{~m}$ among and inside of lines.

In sowing, 12 seeds were placed in each hill, the counting of emerged plants number was accomplished to the 14 days after sowing and registered, with emergency data were estimated the averages to Field Emergency Percentage (FEP) for each genotype, being adopted these values as an indicative of the physiological quality of the seeds. Also was estimated the variance for each genotype, value this, indicative of the potential of each crossing in producing a segregating transgressive of interest.

\section{RESULTS AND DISCUSSION}

None of the exotic big seeds parental overcame in this experiment the parental Doko in field emergency percentage (FEP), while four parentals (Pluto, PI 165676, Biloxi 252N and Tarhell Black) were superior in the experiment realized for Destro (1991), a possible explanation could be in relationship the environmental conditions, causing a different behavior among the experiments, because the involved exotic materials possess low adaptation to our conditions, where any alteration can contemplate in a behavior different from experiments.

The obtained results (Table 1) indicated that the averages of the topcrosses are promising, an increase was observed in the percentage of germination average in various topcrosses in comparison at the exotic feminine parental, where the best performance were of the topcrosses involving the parental: Ivaí crossed with Doko ( $\mathrm{FEP}=54 \%)$, relatively to the parental Ivaí selfcross $(\mathrm{FEP}=5 \%)$ and Hampton crossed with Doko ( $\mathrm{FEP}=50 \%$ ), relatively to the parental Hampton self-cross $(\mathrm{FEP}=6 \%)$, this fact shows that the progenies inherited genes for better physiological quality of the seeds from adapted parental, confirming the recommendation about the use of these for Kaster et al. (1989) as breeding for the character in study.

Some crossings presented FEP values smaller than the exotic parental employed, undesirable fact, but it is explained by the fact that some of the exotic parental chosen already presented high physiological quality of seeds, and the crossing of these with the adapted parental not improved for FEP character, examples observed in the Table 1 are: Tamba crossed with Doko and FT-2; Aliança Preta crossed with Doko; Biloxi crossed with Doko and FT-2; TN \#4 x PI $230970 \mathrm{~F}_{7-4}$ crossed with Doko and FT-2, in all those crossings occurred a decrease in FEP, however due to variance presence (Table 1) segregated transgressives can be selected with promising FEP, inside in this genotypes.

Existed genotypes in self-cross and also in crossings with values very similar to FEP, the obtained plants didn't inherit on the average the genes of adaptability from Doko or FT-2 parental, 
therefore, a new process of topcrosses to obtain a larger progenies number can be interesting, increasing the possibility of the presence of at least a progeny with better FEP. As examples in the Table 1 can make an appointment to genotypes: Nimame crossed with FT-2 and its self-cross; PI 165672 crossed with Doko and self-cross; PI 230977 crossed with Doko, FT-2 and self-cross, among others.

For the variance values occurred the tendency of the progenies overcome yours parents, as example the crossing PI 230977-sel with Doko presented variance of 995 among the progenies, while the parental PI 230977-sel showed variance of 450.

All the obtained variances presented in the Table 1 are promising, the higher values facility the selection of at least one interesting progeny for the program continuity.
Some topcrosses presented smaller variance values in relation to the parental feminine selfcross, with 10 cases in the total, being the most expressive cases for the topcrosses Stwart x Doko and Yamagataken $x$ FT-2. These great variance values in the parental can indicate a strong environmental effect acting in the character in study, due its to have low heritability between 3 and 29\% (Green \& Pinnell, 1968), what without doubt can induce the selection mistakes, therefore the process should be accomplished in a cautious way (discerning), testing the materials by more years and environments before taking place the selection, even so the variances presented by the topcrosses are an indicative of the possibility about the transgressive segregated existence that can its useful for the continuity of the selection process.

Table 1 - Field emergency percentage, averages obtained for until 72 plants for the obtained progenies of the crossings with Doko and FT-2,the self-crosses and until 24 plants for the parentais.

\begin{tabular}{|c|c|c|c|c|c|c|}
\hline \multirow[t]{2}{*}{ Parental } & \multicolumn{3}{|c|}{ Averages } & \multicolumn{3}{|c|}{ Variances } \\
\hline & $\begin{array}{l}\text { Self- } \\
\text { cross }\end{array}$ & Doko & FT-2 & $\begin{array}{l}\text { Self- } \\
\text { cross }\end{array}$ & Doko & FT-2 \\
\hline \multicolumn{7}{|l|}{ Adapted males: } \\
\hline Doko & 73 & & & 213 & & \\
\hline FT-2 & 57 & & & 259 & & \\
\hline \multicolumn{7}{|l|}{ Large seeds females: } \\
\hline Aliança Preta & 52 & 47 & a & 511 & 874 & $\mathrm{a}$ \\
\hline Araçatuba & 30 & 51 & 23 & 656 & 550 & 598 \\
\hline Biloxi 252N (BRA 001201) & 65 & 57 & 58 & 431 & 829 & 652 \\
\hline Cherokee & 21 & 47 & $\mathrm{a}$ & 446 & 604 & $\mathrm{a}$ \\
\hline FC 31-665 & 36 & 53 & a & 395 & 582 & a \\
\hline Hakucho & 07 & 36 & 38 & 81 & 704 & 750 \\
\hline Hampton & 06 & 50 & 39 & 86 & 774 & 633 \\
\hline Hogyoku & 18 & 38 & 52 & 292 & 603 & 456 \\
\hline Ivaí & 05 & 54 & $\mathrm{a}$ & 49 & 672 & $\mathrm{a}$ \\
\hline Japão-1 & 25 & 38 & 37 & 327 & 750 & 792 \\
\hline Japão-2 & 13 & 34 & 36 & 161 & 533 & 690 \\
\hline $\mathrm{KS} \# 3$ x Akiyoshi $\mathrm{F}_{7-2}$ & 39 & 46 & 58 & 609 & 723 & 571 \\
\hline $\mathrm{KS}-473 \times \mathrm{SJ}_{2}-\mathrm{F}_{7}$ & 36 & 51 & 44 & 297 & 595 & 364 \\
\hline Kurakake & 30 & 44 & a & 548 & 755 & $\mathrm{a}$ \\
\hline Late Giant & 11 & 26 & 36 & 147 & 468 & 723 \\
\hline Majós & 26 & 40 & $\mathrm{a}$ & 571 & 489 & $\mathrm{a}$ \\
\hline Mammoth Yellow & 13 & 27 & $\mathrm{a}$ & 298 & 559 & $\mathrm{a}$ \\
\hline Miyashipoken & 17 & 31 & 31 & 414 & 597 & 481 \\
\hline Nimame & 37 & $\mathrm{a}$ & 33 & 554 & $\mathrm{a}$ & 701 \\
\hline PI 80.441 & 23 & 47 & 47 & 385 & 820 & 790 \\
\hline PI 91.725-3 & 24 & 56 & 58 & 416 & 719 & 636 \\
\hline PI 165.672 & 40 & 46 & $\mathrm{a}$ & 378 & 801 & $\mathrm{a}$ \\
\hline PI 165.676 & 29 & 53 & 45 & 379 & 659 & 607 \\
\hline
\end{tabular}




\begin{tabular}{lcccrccc} 
PI 229.320 & 18 & 41 & 54 & 482 & 751 & 584 \\
PI 229.343 & 04 & 29 & 40 & 58 & 513 & 662 \\
PI 230.977 & 52 & 52 & 55 & 382 & 1030 & 682 \\
PI 230.977-sel. & 29 & 60 & 49 & 450 & 995 & 806 \\
PI 243.514 & 05 & $\mathrm{a}$ & 43 & 44 & $\mathrm{a}$ & 756 \\
\hline
\end{tabular}

Table 1 - (cont.) Field emergency percentage, averages obtained for until 72 plants for the obtained progenies of the crossings with Doko and FT-2,the self-crosses and until 24 plants for the parentais.

\begin{tabular}{|c|c|c|c|c|c|c|}
\hline \multirow[t]{2}{*}{ Parental } & \multicolumn{3}{|c|}{ Averages } & \multicolumn{3}{|c|}{ Variances } \\
\hline & $\begin{array}{l}\text { Self- } \\
\text { cross }\end{array}$ & Doko & FT-2 & $\begin{array}{l}\text { Self- } \\
\text { cross }\end{array}$ & Doko & FT-2 \\
\hline PL-1 & 02 & a & 38 & 47 & $\mathrm{a}$ & 601 \\
\hline Pluto & 51 & 63 & 55 & 555 & 682 & 704 \\
\hline Stwart & 44 & 56 & $\mathrm{a}$ & 675 & 470 & $\mathrm{a}$ \\
\hline Tadacha & 45 & 55 & $\mathrm{a}$ & 471 & 584 & $\mathrm{a}$ \\
\hline Tamba & 56 & 41 & 39 & 691 & 571 & 755 \\
\hline Tarheel Black & 61 & $\mathrm{a}$ & 58 & 700 & $\mathrm{a}$ & 636 \\
\hline TK \# 5 x Unknown-F & 43 & 41 & 53 & 678 & 678 & 630 \\
\hline TMV & 14 & 50 & 62 & 217 & 655 & 669 \\
\hline $\mathrm{TN} \# 4$ x PI $230.970 \mathrm{~F}_{7-1}$ & 17 & 56 & 57 & 328 & 563 & 788 \\
\hline $\mathrm{TN} \# 4$ x PI $230.970 \mathrm{~F}_{7-4}$ & 54 & 46 & 42 & 706 & 561 & 802 \\
\hline Wolverine & 01 & 42 & $\mathrm{a}$ & 16 & 711 & $\mathrm{a}$ \\
\hline Yamagataken & 27 & 36 & 41 & 736 & 628 & 562 \\
\hline $64-64 \times$ KS-473 & 15 & 53 & 54 & 161 & 840 & 612 \\
\hline \multicolumn{7}{|l|}{ Small seeds females: } \\
\hline IAC Santa Maria-702 & 85 & 66 & $\mathrm{a}$ & 318 & 485 & $\mathrm{a}$ \\
\hline Imperial & 37 & 60 & 59 & 311 & 646 & 500 \\
\hline PI 80.459 & 39 & 60 & 69 & 254 & 563 & 482 \\
\hline
\end{tabular}

a: crossings for which were not obtained seeds.

The Table 2 show the FEP average and variance average to 41 exotic parental (37 with big seeds and 4 with small seeds) self-crosses and in crossing with Doko and FT-2, could be observed that crossings involving parental with big seeds elevated the FEP average to lineages of 28 for $46 \%$, intermediary values between the exotic lineage with large seeds (28\%) and the adapted parental $(65 \%)$ and for the small seeds of 54 in self-cross for more than $60 \%$ in crossing, a great progress for the character, behavior similar to the obtained for Destro (1991), and the crossings involving the materials with small seeds approached a lot of the observed for the two adapted parental.
For the averages of the variances, the crossings with Doko and FT-2 presented promising values for the new lineage selection, and in the crossings involving the exotic parental with big seeds was observed the largest values, 673 and 656 respectively, representing a great variability. In the crossings with small seeds parental has smaller variance averages (565 and 491), but this doesn't signify that inside of these crossings doesn't exist variability, on the contrary, it exist. The crossings presented superior variability in comparison at the lineage per se, reflecting an increase of the genetic base in the tested materials, fact wanted in an improvement program (Vello, 1992).

Table 2 - Medium values and of variances of field emergency percentage for the parental and for the topcrosses of large and small seeds. 


\begin{tabular}{lcccccc} 
& Self-cross & Doko & FT-2 & Self-cross & Doko & FT-2 \\
\hline Adapted & 65 & & & 236 & & \\
Larges & 28 & 46 & 46 & 386 & 673 & 656 \\
Smalls & 54 & 62 & 64 & 294 & 565 & 491 \\
\hline
\end{tabular}

\section{CONCLUSIONS}

For the obtained results can be observed that promising results were reached for the field emergency percentage (FEP) in various topcrosses, and the problem about low physiological quality was outlined in almost everybody, existing enough variability inside for selection of at least a progeny in the case where the FEP average was not favorable.

\section{RESUMO}

Esforços foram feitos para estudar o efeito da introgressão de genes para alta qualidade fisiológica de sementes de cultivares adaptados na soja alimento (considerados exóticos). Resultados promissores foram obtidos para todos os topocruzamentos, com aumento na porcentagem de germinação na maioria dos materiais avaliados. A média geral da porcentagem de germinação nos topocruzamentos com parentais exóticos de sementes grandes mostraram aumentos de 28 a $46 \%$, e topocruzamentos com parentais exóticos de sementes pequenas de 54 a mais de $60 \%$, ambos os casos comparados com os parentais exóticos auto fecundados. Em relação a variância, os topocruzamentos apresentaram valores maiores do que os parentais exóticos auto fecundados, mostrando a possibilidade de seleção de soja alimento com sementes com maiores porcentagens de emergência.

\section{REFERENCES}

Agrianual (1998) Anuário da Agricultura Brasileira. São paulo: FNP Consultoria \& Comércio . p.355-388.

Carrão-Panizzi, M. C. (1987) Soja: proteína para milhões. Ciência Hoje, 6, 25-31.
Destro, D. (1991) Capacidade de combinação de genótipos de soja [Glycine $\max$ (L.) Merrill] apropriados para o consumo humano. Tese de Doutorado, Escola Superior de Agricultura "Luiz de Queiroz", Universidade de São Paulo, Piracicaba, São Paulo, Brasil.

Green, D.E.; Pinnell, E.L. (1968) Inheritance of soybean seed quality. I. Heritability of laboratory germination and field emergence. Crop Science, 8, 5-11.

Guerra, E.P.; Destro, D.; Miranda, L.A.; Montalván, R. (1999) Performance of food-type soybean genotypes and their possibility for adaptation to Brazilian latitudes. Pesquisa Agropecuária Brasileira, 34, 575583.

Kaster, M.; Paludzyszyn Filho, E.; Kiihl, R.A.S.; Krzyzanowski, F.C.; Carbonell, S.A.M. (1989) Mejoramiento de la calidad fisiológica de la semilla de soja y metodologia de evalucíon. Paper presented at 4th World Soybean Research Conference, Buenos Aires, Argentina. 1106-9.

Kiihl, R. A. S.; Garcia, A. (1989) The use of long-juvenile trait in breeding soybean cultivars. Paper presented at 4th World Soybean Research Conference, Buenos Aires, Argentina. 994-1000.

Paschal II, E.H.; Ellis, M.A. (1978) Variation in seed characterisitcs of tropically grown soybeans. Crop Science, 18, 837-840.

Rao, S.K.; Sharma, S.M. (1985) Genetic variation for pod characteristics and their inter-relationships with field germinability in soybean. Indian Journal of Agricultural Research, 19,150-154.

Santos, A. L. C. (1988) Variabilidade entre genótipos de soja (Glycine $\max (\mathrm{L}$.) Merrill) nas fases imatura e madura de desenvolvimento. Dissertação de Mestrado, Escola Superior de Agricultura "Luiz de Queiroz", Universidade de São Paulo, Piracicaba, São Paulo, Brasil.

Sung, F.J.M. (1992) Field emergence of edible soybean seeds differing in seed size and emergence strength. Seed Science and Technology, 20, 527-532.

Vello, N.A. (1992) Ampliação da base genética do germoplasma e melhoramento da soja na ESALQ-USP. In: Simpósio sobre cultura e produtividade da soja. Ed. G.M.S. Câmara; J. Marcos Filho; E.A.M. Oliveira. FEALQ. Piracicaba. pp.60-81.

Vernetti, F.G. (1983) Genética da soja - caracteres qualitativos In: Soja: genética e melhoramento. ed. F.G. Vernetti. Fundação Cargill. Campinas, pp.467-721. 
Wien. H.C.; Kueneman, E.A. (1981) Soybean seed deterioration in the tropics. II. Varietal differences and techniques for screening. Field Crops Research, 4, 123-132.
Received: June 08, 1999; Revised: July 15, 1999; Acccepted: October 10, 1999. 